The McCarron Lectures*

\section{Lecture 3: Plato and Persuasion}

\author{
Gary McCarron
}

Simon Fraser University
Scholarly and Research

Communication

VOLUME 12 / ISSUE 1 / 2021

\begin{abstract}
Socrates conversed and Plato recorded, bringing together an entwined version of their notion of rhetoric. How do we balance absolute truth with opinion, belief, and conjecture? This lecture centres on the dialogue Gorgias plays to Socrates/Plato's notion of rhetoric as a fully formed social practice; it illustrates the practice and study of persuasion.
\end{abstract}

Keywords: Socrates, Plato, persuasion, rhetoric

\section{Résumé}

Socrate parla et Platon enregistra, réalisant ainsi une version combinée de leur notion de rhétorique. Comment équilibrer la vérité absolue avec l’opinion, la croyance, et l'hypothèse? Ce cours se focalise sur le dialogue de Gorgias relatif à la notion socratique/platonicienne de la rhétorique comme étant une pratique sociale complètement formée; le cours fournit une illustration de la pratique et de létude de la persuasion.

Mots clés : Socrate, Platon, persuasion, rhétorique
Gary McCarron is Associate Professor in the School of Communication at Simon Fraser University. Email: gmccarro@sfu.ca

* Please see Editorial: Syntheses, Reflections, and Conjectures in Scholarly and Research Communication: $\mathrm{SRC}^{1+1}$.

* These lectures are provided with the understanding that when used in class you consider fair use, providing a payment of $\$ 10$ per student. These funds will be forwarded to the author. Please contact Marilyn Bittman, Managing Editor, SRC, for further payment information: bittmanme @shaw.ca

\title{
Introduction
}

Now that we have talked about the Presocratics, let us move ahead and discuss Plato's philosophical account of rhetoric as it is chronicled in the Socratic (sometimes called the Platonic) dialogues. As you probably know, Socrates criticized the development of alphabetic writing and never recorded his ideas in written form. Hence, we must look to his student Plato, who allegedly constructed the dialogues from his memories of Socrates' teachings and put them down in writing. There is a long story to be told about the fact that Socrates preferred speaking to writing, and much has been said about his reasons for opposing writing, pointing out that his arguments can still be used to critique modern communication technologies. I will come back to this point,

McCarron, Gary. (2021). The McCarron Lectures. Lecture 3: Plato and Persuasion. Scholarly and Research Communication, 12(1), 25 pp. doi:10.22230/src.2021v12n1a367 
Scholarly and Research

\section{Communication}

VOLUME 12 / ISSUE 1 / 2021 but for the present, we will simply note that whereas Socrates wandered the alleys and byways of ancient Athens speaking to whomever he could corner or cajole into conversation, it was Plato who turned these conversations into the written dialogues we have today.

One of the first things we learn about Socrates from the dialogues is that as he walked the streets of Athens, he annoyed people-including city officials-with his persistent questioning. ${ }^{1}$ Of course, many people were willing to debate him, otherwise we would not have the Platonic dialogues, but there is little disputing that Socrates was a nuisance to many Athenians. His habit of questioning and upsetting people was not an indiscriminate attempt to annoy, however. Socrates was systematic in his interrogations, practicing his philosophy with a method known as the dialectic. We will explore this in more detail later, but it is helpful to note that the word dialectic is etymologically related to the word dialogue, and thus yields the conversational quality of the Dialogues. So, whereas Socrates never wrote anything down, he developed his philosophical ideas through a method-the dialectical approach-that privileges the role of speech and inquisition. In Socrates' method, one does not consult the writings of earlier philosophers as these are recorded in texts; rather, one consults everyday people in conversation based on the assumption that with the proper use of questions, even the philosophically untrained will be able to assist in the goal of coming to an understanding of truth.

Because Plato wrote the dialogues following the death of Socrates in 399 BCE, they are a mix of ideas from both men, and this has spawned an ongoing debate as to which parts of the dialogues can be attributed to Socrates and which should be credited exclusively to Plato. As I am offering only a brief overview of the thought of Socrates and Platoand even more narrowly, an account of their understanding of rhetoric-many of the debates about authorship and chronology that interest scholars of ancient Greece are safely outside the circle of concern of this lecture.

In Plato's dialogues, we encounter the notion of rhetoric as a fully formed social practice-a university subject, in a sense-complete with techniques based on an elementary understanding of human psychology. ${ }^{2}$ Plato's (1997a) writings also help us to understand rhetoric as something about which there can be antagonistic debate, as we see in the dialogue Gorgias, where Socrates spars with opponents, including Polus, Callicles, and the famed rhetorician Gorgias. What we see in the dialogues concerning rhetoric, then, are discussions that would have been part of a tradition of both the practice and study of persuasion and its usefulness in Athenian society. We also are introduced to the idea that rhetoric is very much a philosophical concern.

The fact that the ancient Athenians were so deeply concerned with rhetoric-or what they often called oratory-may seem odd to modern readers. In fourth-century BCE Athens, however, all men who were not slaves were required to serve terms in government on a rotating schedule, so it was important to be able to speak eloquently in front of large groups. Moreover, court trials required that the accused and the defendant presented their own cases, so it was valuable to have a solid understanding of public oration if one hoped to prevail in a legal dispute. In ancient Athens, persuasive speaking was a vital requirement of civic life.

McCarron, Gary. (2021). The McCarron Lectures. Lecture 3: Plato and Persuasion. Scholarly and Research Communication, 12(1). doi:10.22230/src.2021v12n1a367 
In addition to presenting rhetoric as an important if contested subject, the Platonic dialogues introduce several famous rhetoricians-people who instructed others in the art of persuasive speaking, such as Gorgias-and it is in Plato's conversations with these teachers that we learn about his attitudes toward oratory. ${ }^{3}$ What is that attitude? As with many of the things he writes about, Plato is not entirely consistent about rhetoric across the entire collection of dialogues. His assessment of rhetoric also moderated as he grew older; later in his life, he sought to distinguish between good and bad rhetorical practices, a distinction that suggested he came to understand that persuasion might be a good skill to master in some circumstances. I am going to focus, however, on a set of arguments regarding rhetoric that Plato advanced before he softened his views-the view with which he is most closely associated today-his idea that persuasion and truth are often diametrically opposed. Indeed, Plato claimed that the goals of persuasive speech can sometimes be at odds with his idea of the most noble philosophical ambition: to always seek the good. A central point of this lecture, therefore, is to review Plato's objection that rhetorical training is a procedure that ultimately served to deter people from attempting to achieve the ideal ethical state he believed it was our obligation to strive for. In seeking to persuade others, Plato complained, we often try to draw them away from the truth, and for Plato, there was no greater evil than to distract oneself and others from the search for the truth.

Indeed, one of the central questions that we will come back to is whether the compliance professional of today speaks from a condition of moral worthiness or from a condition of mere skill acquisition. Is rhetorical talent an important credential of the moral person, or do we tend to mistrust such people because we are doubtful of their motivations? To put that still another way: is persuasive language used more often to lead us to the truth or to lead us away from it? Plato certainly believed the latter, and if some of us are inclined to feel dubious about the intentions of people who seem keen on persuading us of one thing or another, the Platonic dialogues figure large in the history of these suspicions. Throughout Western history, skillful orators often appear in the image of a medical quack hawking the latest magical elixir said to cure all ailments, or a politician promising that her policies are sure to lead to a safer and more prosperous society; thus, misgivings about the intentions of talented persuaders persist to this day. This is one of the issues that can be found in the Platonic attitude toward rhetoric.

Plato's analysis and critique of rhetoric can be described as both famous and infamous depending on your view of his philosophical project. My own view is that Plato misses the mark in several important respects but that his overall argument is ingenious and, if I might be permitted, persuasive. This lecture will be constituted mainly from three specific themes. First, I will say a bit about the social world into which Plato was born. Second, I will ask your indulgenceva rhetorical procedure, by the way-as I return briefly to the Presocratics and describe the ideas of two famous Presocratic philosophers, Heraclitus and Parmenides. I will go over their views on an important and unresolved metaphysical problem that forms the opposing ends of a debate that was important in Plato's time and had considerable influence on his thinking about rhetoric. Third, I will discuss the other key influence on Plato's view of rhetoric, the sophists, a group of itinerant philosophers who taught the art of public persuasion to upper-class

McCarron, Gary. (2021). The McCarron Lectures. Lecture 3: Plato and Persuasion. Scholarly and Research Communication, 12(1). doi:10.22230/src.2021v12n1a367
VOLUME 12 / ISSUE 1 / 2021 


\section{Scholarly and Research}

\section{Communication}

VOLUME 12 / ISSUE 1 / 2021 men and charged a fee for their services (Gorgias, for instance, was a sophist). The sophists are really the first recognizable rhetoricians insofar as their stated goal was instruction in the art of persuasive speaking. As we will see, elements of Presocratic philosophy combined with Plato's attitude toward the sophists played a big role in his assessment of rhetoric, for Plato sought to resolve the debate between Heraclitus and Parmenides at the same time as he sought to refute the basic principles embraced by the sophists. This is the essential context for his notion that rhetoric is a dangerous social practice. The main points of this argument are not terribly complicated, but they do require a bit of unpacking. But first, let me start with some basic information about Plato.

\section{Background of Plato}

Plato was born in 427 BCE to an aristocratic family, although Plato himself seems to have possessed no great wealth during his lifetime. His father, Ariston, is something of a mystery to historians, but it is thought that he was a direct descendant of the last of the Athenian kings. His mother, Perictione, was a direct descendant of Solon, the Greek statesperson famous for drafting the constitution that established Athenian democracy, although calling Solon's Athens "democratic" means overlooking practices that would hardly be democratic by contemporary standards. Athens was a slave-holding culture and formidably patriarchal, though its historical defenders are quick to point out that compared to other city states of the time, it was far more advanced culturally and politically. This may well be true, but the main point to bear in mind is that Athenian democracy was itself already a contested idea in Plato's time. It was also a political system to which Plato was not sympathetic.

Athens' most famous and possibly most beloved leader during Socrates' life was Pericles, who oversaw the construction of the Acropolis and the Parthenon during his rule. He is said to have been an intelligent and cultured person who claimed many philosophers (including some Presocratics) among his circle of friends. He once famously referred to the city state over which he ruled, Athens, as the "school of Greece," a title that reflected his goal of spreading culture widely throughout the whole of Athens and into neighbouring city states. He was also an accomplished and talented orator.

Pericles presided over Athens at its political, intellectual, and cultural zenith. His reign is often referred to as the Golden Age of Pericles, and many later writers, including Nietzsche, looked back on fifth-century BCE Athens as the pinnacle of human political accomplishments. But though Pericles' reign was great, it was not without difficulties. During his time as ruler, Pericles was forced to withstand many invasions, including assaults from neighbouring Greek city states and attacks from Persia, a powerful enemy of Athens. Athens itself was a dominant cultural and military force with an especially large navy, and Pericles was an excellent military campaigner ably assisted by several generals who history records as brilliant strategists. For instance, the Greek historian Herodotus said that Athens once turned back a Persian army he estimated at 1.7 million men. Modern historians have contested the accuracy of this estimate, but there is general agreement that Athens indeed turned back an armed force that seemed in every respect its numerical superior. During his reign, then, Pericles was constantly forced to maintain a heightened sense of military vigilance.

McCarron, Gary. (2021). The McCarron Lectures. Lecture 3: Plato and Persuasion. Scholarly and Research Communication, 12(1). doi:10.22230/src.2021v12n1a367 
During Pericles' reign, however, Athens entered the Peloponnesian War against Sparta and its allies. The conflict that lasted from 431-404 BCE, and Athens did not emerge triumphant. ${ }^{4}$ At the outset of the war, Pericles adopted an unusual strategy and refused to engage the Spartans on the battlefield, instead using his city's naval power to distract the Spartans by attacking Spartan allies and supply vessels. Many of Athens' aristocratic citizens were concerned that this tactic would fail and that the Spartans and their allies would continue to increase in strength. It is difficult to know whether these worries were well-founded because shortly after the war started, a plague broke out in Athens and decimated the population, the disease carrying off Pericles as one of its many victims. From that point forward, the war lurched ahead with both sides accumulating casualties, but Athens, reeling from the plague and the loss of Pericles, was increasingly on the defensive. The tide of the war turned against the Athenians until finally, in 405 BCE, a Spartan fleet destroyed most of the Athenian navy at the Battle of Aegospotami. With no ships to import grain and other food, the Athenians faced the prospect of starvation, and Athens surrendered to Sparta. The city states of Corinth and Thebes, which had sided with Sparta, called for the destruction of Athens and the enslavement of all its citizens, but the Spartan leaders, committed to principles of honour, refused to subject the Athenians to further humiliation.

Immediately after this defeat, the so-called Rule of Thirty began: a reign of terror led by pro-Spartan members of the Athenian aristocracy. In its ranks, the group had members of Plato's family, including his uncle Charmides and his cousin Critias, who was regarded as among the cruelest of the Thirty. This brutal regime sought to transform Athens from its limited democracy into an absolute oligarchy, a plan they carried out by means of exile, execution, and terror. Plato mentions the Thirty at several places in the dialogues, and he is vocal in his opposition to their authoritarianism. He also mentions an incident involving Socrates during the time of the Thirty that he says made evident his teacher's considerable moral character.

According to Plato's account, the Thirty called Socrates and four other citizens to a meeting and instructed them to carry out the arrest of Leon of Salamis and bring him before a tribunal. Socrates flatly refused, knowing Leon to be innocent of any crimes. Then, having shocked the Thirty with his outright refusal to comply, Socrates promptly stood up, left the meeting, and serenely returned to his home. His refusal to follow through with an order he considered unjust spoke loudly of his commitment to his principles, and the calmness with which he carried himself is said to have illustrated his equanimity. The other four citizens who were given the task of arresting Leon carried out the order out of the fear that defiance would result in their own executions. Perhaps worried over the possibility of public protest should they arrest Socrates, the tyrants decided to ignore his act of public disobedience and left him alone. ${ }^{5}$

Acts of terror, such as the arrest of Leon, were used to demoralize and control the population, but as with many campaigns of terror, the strategy eventually came to backfire. Desperately hated by most Athenians, the Thirty were overthrown after only thirteen months in power. Still, their brutal campaign to remake Athens into an oligarchy left terrible marks on the city: it is estimated that five percent of the city's population was executed during their short reign. 


\section{Scholarly and Research}

\section{Communication}

VOLUME 12 / ISSUE 1 / 2021
So, what we have is the following: Plato was raised in an aristocratic household that opposed Pericles because they felt he was waging a military campaign doomed to failure. Plato was also surrounded by people who disliked democracy and viewed it as a dangerous and inefficient form of government. He had also thought the philosophy for a new order would come from his teacher, Socrates, but when the Rule of Thirty ended, democracy (of a sort) was re-established in Athens, much to Plato's disgust. In addition, the new Athenian democracy, fragile and uncertain of itself, was sensitive to criticism, and Socrates had a particularly sharp tongue when it came to criticizing the leaders of Athens (he was after all, a pest, a gadfly). He was told to stop his teaching but refused, and he was eventually brought to court and sentenced to death. Thus, Plato not only saw democracy-which he despised-re-established in Athens after the Rule of Thirty, he also saw the man he envisioned as the architect of a new world put to death by the very people Plato believed should have been heeding Socrates' counsel. It is hardly surprising, then, that Plato devoted so much of his intellectual energy to thinking and writing about the perfect civil society.

Plato (1997b) attended Socrates' trial and recorded his teacher's famous Apology for posterity. ${ }^{6}$ Some commentators suggest that Plato was concerned about recording Socrates' exact words out of the fear that Socrates' enemies would circulate less accurate accounts of what he said in his defence. However, most historians believe the Apology, though an effective paraphrase, contains a good deal of Plato's own thoughts, and is not intended to be read as an actual transcript of what was said in the proceedings. The trial concluded in 399 BCE with a guilty verdict and death sentence, and Socrates voluntarily drank a poisonous draught. Socrates did not want to die, of course, and his friends made plans for his escape that could easily have secured his freedom. But as a citizen of Athens, Socrates believed himself bound by a duty to obey the city's rules. Without obedience from its people, he told his friends, a city cannot survive, and although his death would be lamentable, it was required by the very philosophy that he had preached his entire life. I am sure you will not be surprised to hear that many writers have noted parallels between the lives of Socrates and Jesus.

Out of fear for his own safety following Socrates' trial, Plato left Athens and spent time in Syracuse, where he hoped to convince King Dionysius to establish a just and non-democratic government along the lines that Plato (1997d) outlined in his most famous work, The Republic. However, jealousies at court and other problems militated against these plans, and Plato returned to Athens. One story tells of how he was sold into slavery on his return trip and had to be ransomed by friends. Safely back in Athens, he established his school, the Academy, and taught there until his death in 348 BCE at the age of 80 .

\section{Plato's influences}

There is a great deal more to Plato's life and teachings, but I want to keep our overview to a reasonable length. Hence, I am not going to discuss his major work, The Republic (Plato, 1997d) (though I will mention it), or his last significant book, The Laws (Plato, 1997c), where he partly repudiated some of his earlier ideas and advocated for a kind of theocracy. I will also not discuss what many consider his greatest dialogue, The Symposium (Plato, 1997e), which deals with the subject of love and displays Plato's growing interest in an idealist philosophy. I am not ignoring these works because I regard 
them as unimportant, but simply because they do not advance our discussion as it pertains to rhetoric. So, we will be discussing a rather narrow slice of Plato's corpus.

I will expand on the context concerning Plato's various influences by introducing two Presocratic philosophers, Heraclitus and Parmenides. Following a discussion of their respective philosophical viewpoints, I will consider the ideas of the sophists. Then, I will show the nature of their application to his ideas about rhetoric.

\section{Plato and the Presocratics}

Let me begin with a quick review of what we have already said about the Presocratics. They began their investigations by asking about the nature of the cosmos and if there is a fundamental element, an arche, out of which everything is made, or a fundamental principle that underlies the nature of reality. And while they agreed that there are multiple elements in the world, they did not agree unanimously as to the fundamental constituent of nature (what things are made of), nor did they agree on the fundamental character of reality. Thus, two essential questions pre-dated Socrates and Plato: What is the fundamental nature of the cosmos? What is the cosmos made of?

As we have noted, some philosophers, such as Thales, took the view that everything comes from water, but the second question about the essential nature of reality is a more interesting question for contemporary thinkers. This is because inquiries about the essential nature of reality are metaphysical at their heart, and while there are implications for scientific investigation depending on how one tries to answer this question, its abstract character allows for broad philosophical (and theological) interpretations. For example, consider the simple fact that the universe exists. Why does it exist? Is it not just as logical that there would be nothing rather than something? Why is there something rather than nothing?

The ancient Greeks also asked why there is something rather than nothing, but there was a further metaphysical question they found equally puzzling. Indeed, this question ultimately divided the Presocratics into two camps and led to considerable philosophical debate and discussion. The Presocratics wanted to know if nature is permanent and indivisible, or if it is fundamentally processual and always changing, or in flux. This can be put even more plainly: is everything changing, or does everything remain the same? Even today, first-year philosophy students often spend a good deal of energy wondering whether things are ultimately permanent or forever in flux. Thus, we have two propositions: everything is forever the same, a state of permanence, or everything is forever in flux, a state of becoming. This gives rise to an obvious problem: the two positions are absolutely diametrically opposed and, therefore, a resolution must be found. For our purposes, one way to try to make sense of the dilemma is to look a little more closely at the arguments as they were actually presented by the philosophers themselves. The Presocratic philosophers who epitomize the two sides of this debate were Heraclitus of Ephesus (modern-day Turkey) and Parmenides of Elea (modern-day southern Italy).

Heraclitus, who argued for the principle of change, denied that anything could stay the same. He particularly denied that anything could be identical with what is, has been, or

McCarron, Gary. (2021). The McCarron Lectures. Lecture 3: Plato and Persuasion. Scholarly and Research Communication, 12(1). doi:10.22230/src.2021v12n1a367 


\section{Scholarly and Research}

\section{Communication}

VOLUME 12 / ISSUE 1 / 2021 will be. In short, he denied any permanence or immutability in the world. His most famous aphorism sums up his view with poetic economy: "One cannot step twice into the same river." 7 His meaning may seem odd at first, but it is easily interpreted. Because the river is forever changing, and because we ourselves are forever changing, no two episodes in time can ever be said to involve the same exact phenomena. The river is always changing as it flows; similarly, we are never the same person from moment to moment, for we too are forever changing, even if the ways we change moment to moment are imperceptible. The molecules of water that were here a moment ago are now far downstream; the person I was a moment ago has disappeared as cells have died off, hair has fallen from my head, I am seconds or minutes older, I am imagining different thoughts, and so on. This is the basis for the claim that nothing is identical with what is. In much the same way that time is never fixed at one instant but is always moving forward, Heraclitus said the world was in constant flux. Furthermore, Heraclitus' work suggested that reality, in being fundamentally mutable (changeable), is also composed of contraries, or opposites, a principle reminiscent of the ideas of Anaximander. Indeed, Heraclitus argued that because we see change all around us, this constant transformation is best understood as the unity of oppositions, for this is the basic nature of all the different forms of change we see: cold changes to hot, wet changes to dry, living things change to dead things, and so on. The world only exists because of these contraries, each calling its opposition into being.

Some of the followers of Heraclitus were so enthralled by his ideas that they adopted an even more radical position that he advocated. A radical Heraclitean doctrine holds that no knowledge of the world is possible since there is no prospect of ever fixing anything as true at any given moment. Why? Because as soon as we think we know the nature of a thing, it immediately changes into something else. By the time I think I know you, you have actually changed by growing two seconds older, and so I do not really know the you that is you now. Indeed, I am also constantly changing, so any claim I might make to know anything is doubtful since I am not the person who made the initial observation! ${ }^{8}$ We might even say that self-knowledge under such conditions would be equally impossible. Such an extreme view of Heraclitus' philosophy was adopted by Cratylus of Athens, who allegedly argued that not only can one not step into the same river twice but one cannot even step into the same river once. ${ }^{9}$ It is believed that Plato's views of Heraclitus were derived in part from his familiarity with the more radical positions of Cratylus, who is said to have had some influence on the young Plato.

While Heraclitus is a good example of a Presocratic philosopher who stood for the idea that the basic principle of the cosmos is ongoing change, Parmenides is a good example of a philosopher holding the opposite view. Parmenides argued that reality is unchanging, imperishable, and indivisible. In short, it is not change that underlies reality but permanence. This idea may be harder for modern readers to grasp, partly because Parmenides describes the idea of permanence in mythological, almost supernaturalistic language. In fact, Parmenides presented the main outline of his philosophy in a long poem that relies on a series of mystical images and events, and this makes it difficult to present his thesis of cosmic permanence in more traditional logical discourse. ${ }^{10}$ Therefore, the language that is used in promoting the metaphysics of permanence often 
sounds more theological than philosophical. Nonetheless, the idea was popular in Plato's day and is still regarded by some contemporary philosophers as an important notion.

In opposing Heraclitean flux, Parmenides did not merely proclaim the sovereignty of permanence but offered an interesting argument that received a more detailed and reasoned account from later followers. Parmenides said that Heraclitus was wrong because if we say that change is the essence of reality, we must also accept the existence of a condition of not-being. Not only that, but to say that something that is cannot be - that is, to say something that exists also cannot exist-is clearly to accept a contradiction in terms.

You are probably confused, for the condition of not being can be hard to grasp. Still, the basic argument is not impossible to follow. First, Parmenides says that whatever there is that is, is uncreated. Put another way, nothing can be created but must always have been-remember, he is privileging the idea of permanence-because the idea of creation suggests a beginning point. Furthermore, if something is created, this means that before its creation, it could not have existed and an enormous change has taken place. But if change is impossible, then so is creation, because creation would be the ultimate act of change-bringing something into being from nothing.

Let us think this through a little further. Before creation there would have been nothing, and nothing cannot lead to something_or so Parmenides argued, along with certain theologians who, even today, suggest that God and the universe have always existed. According to Parmenides' doctrine of permanence, then, a beginning (or an end, for that matter) do not even make sense because there cannot be a point of creation. In addition, Parmenides says that nothing is a concept that does not name any intelligible thing or idea. One cannot even think of nothing without bringing something to mind. Hence, there is no individual thing in the universe that was ever created-everything that is, just is. No change on so grand a scale as would be required by creation is possible, for to argue that a thing is transformed into something else is to claim that this thing becomes what it was not (the old thing disappears, and the new thing appears). But there is no nothing for the old thing to disappear into.

Consider a simple if unsophisticated example. This example is incomplete in several respects as it applies to Parmenides' views, but it will help make at least a few of the substantive points. Let us begin with a dubious proposition: $\mathrm{H}_{2} \mathrm{O}$ must be in a particular state, and among those states, we can identify ice and water as two of the most obvious. Now, if you put an ice cube on a table at room temperature, you will note that at some point, the original thing is no longer an ice cube, but it is not yet entirely water either. It is neither completely water nor completely an ice cube. In this state, then, it would appear to be nothing (so long as you accept that it must be either ice or water, a condition that can certainly be disputed). But because nothing is an impossible condition, the ice cannot change into water since no object can enter a condition in which it is nothing. Naturally, there are intimations of other kinds of paradoxes involved here, such as Zeno's famous argument that an arrow can never reach its target. 


\section{Scholarly and Research} Communication

VOLUME 12 / ISSUE 1 / 2021
Now, to the best of my knowledge, Parmenides never used the example of melting ice, and it is not entirely in keeping with his philosophy, which is somewhat more elaborate than this illustration suggests. However, historians are agreed that Parmenides fully accepted the paradoxical implications of his doctrines, and although we cannot be certain how he would have approached the example of ice melting into water, it would appear that he would have embraced the paradox of that example. He was committed to the idea that the universe (the what is) can be thought about and imagined, while what does not exist (the what is not) is unthinkable. Therefore, Parmenides said, we speak nonsense in trying to talk about what is not, for it is unthinkable and unsayable. We can speak intelligently only about what is, and what is must have always been. You cannot even think of nothing as there will always be something in your thinking, so you are speaking gibberish if you try to speak of that which is not.

Parmenides' contemporaries and the philosophers who followed were not always convinced. Aristotle complained that although Parmenides appears to be following an acceptable line of logical reasoning, it is obvious that something, somewhere, has gone wrong with his argument. Aristotle was very much a materialist, and though he wrote about metaphysics, there were limits to what he would accept as a solid, metaphysical position. Plato approached the challenges raised by Parmenides from a different point of view, he tried to make sense of what Parmenides was actually saying. In particular, Plato sought to disentangle the different ways in which we use phrases such as what is not. According to Plato, Parmenides' chief problem may have been that he was not always consistent in his wording, and this inconsistency ultimately undermined his arguments. For instance, Plato pointed out that things can be in a condition of what is not in different ways - that is, there are things that might not be, but they might not be (that is, might not exist) for all sorts of different reasons. A unicorn, for instance, is one of those things that is not. But the reason for a unicorn not being a real thing is because it does not, never has, and never will exist in reality. And this way of not being is an entirely different way of not being than the apple I have just eaten and that, therefore, no longer exists as an observable thing in the world. Because it is fantasy, the unicorn is not; the eaten apple is also not, but for an entirely non-fantastical reason: it is gone. The unicorn is not because it never existed; the apple is not because it is now in my stomach. Therefore, things can be in the condition of not being for different reasons. In trying to explain the problem he identified in Parmenides, Plato also claimed that there was still something important to Parmenides' argument, and that in the end, the venerable Presocratic had mainly just expressed himself poorly.

Did Heraclitus win the debate, then? Not really, and rather than toss Parmenides aside, we might consider the value of his philosophy as residing in its appeal to the notion of paradox. To do this, we can examine the ways we understand and value paradox in the modern world. For instance, think about the problems and paradoxes that are a part of particle physics. Take the question of light as an example: is it a particle or a wave? It all depends on the nature of the experiment. Or ask whether we can simultaneously measure both the location and speed of a sub-atomic particle. The answer is no, we can measure either or its position or its speed, but not both things at once. To put it plainly, paradox remains a vital part of science, philosophy, and religion, and so we should perhaps be willing to accept that Parmenides might have been on to something. In fact, Christian theologians in 
Medieval times liked the implications of Parmenides' work very much as they imagined it applied to Christian doctrine, since it suggested that everything that exists is part of what he called "the One." They also valued his idea that there is no condition that precedes creation and used this notion to claim that it supported the Christian doctrine that God is uncreated and has always existed. God also never changes-he does not even change his mind - and thus the early church fathers of Christianity were far more sympathetic to Parmenides than they were to Heraclitus (see Clark, 2002).

At this point, I will beg off explaining how these arguments proceeded down the centuries, as we are now moving outside the borders of debate as it was carried out in Plato's time. The main thing to take away is that two different answers were offered in response to the metaphysical question of the nature of reality. Some favoured the thesis of unchanging permanence, while others preferred the concept of perpetual change. And the implications of this debate were considerable insofar as they affected the way that people thought about truth and the possibilities of knowledge. Plato's philosophical ideas, therefore, include the Presocratic debate about the metaphysics of nature. This debate also resonates in contemporary classrooms where students study rhetoric. When someone successfully persuades you about something, you might say that you have changed your mind, and this would appear to favour the philosophy of Heraclitus. But the you who changes his or her mind must be stable over time if that mind is to be recognizable as belonging to you, a point that favours the philosophy of Parmenides. After all, it has to be the same you who changes your mind for the shift in opinion to be meaningful. So, the debate pitting permanence against change can lead to some interesting social and cultural issues. This is one of the reasons that contemporary rhetoricians often ask what happens when someone's opinion is "changed." What changes when someone changes their mind? Do they change along with their opinion (see Burke, 1984)? This question falls outside the scope of this inquiry. I will leave it to you to puzzle over and move on to the next part of the Socratic critique of rhetoric: the dreaded sophists.

\section{The sophists}

This debate over the question of permanence seems insoluble, and yet Plato eventually figured out a way to solve it, to answer the question of whether the cosmos is in a state of permanent, unrelenting change or a state of absolute permanence. Before we go to Plato's resolution, however, there is one further influence on his thinking regarding rhetoric: the ideas of a group of philosophers known as the sophists. I will touch briefly on the sophists and then show how in dealing with the problems raised by the sophists and answering the Presocratics' question about the nature of the cosmos, Plato formulated an ingenious theory of rhetoric whose legacy is with us today.

The name sophist gives us several English words, including sophistry (meaning a faulty argument intended to deliberately mislead) and sophisticated (meaning educated, cultured, or experienced). These two words are quite different in tone-sophistry is negative and sophisticated is positive. This hints at something ambiguous about the sophists themselves: were they sophistical or were they sophisticated?

In the world of rhetoric, the sophists are a curious group, for while they were teachers of rhetoric who developed important and elaborate techniques for public oratory, their

McCarron, Gary. (2021). The McCarron Lectures. Lecture 3: Plato and Persuasion. Scholarly and Research Communication, 12(1). doi:10.22230/src.2021v12n1a367 


\section{Scholarly and Research}

\section{Communication}

VOLUME 12 / ISSUE 1 / 2021 name can also suggest deliberate deception and trickery. ${ }^{11}$ In this respect, it is commonly suggested that the sophists were regarded in much the same way as people speak of contemporary lawyers: they are suspicious of their tactics but respectful of their skills. Making the weaker argument appear the stronger is often required in legal proceedings, and should you find yourself in need of legal representation you would likely want a lawyer who could effectively argue your case-perhaps even if it meant dazzling and confusing the court and jury to ensure victory. As a dedicated student of philosophy, however, you might look unfavourably on someone who twists words to confuse the court, uses questionable linguistic tactics to gain an advantage, and manipulates innocent jurors to agree to dubious arguments. As the Irish writer, Jonathan Swift (2005) wrote, lawyers are trained "in the art of proving, by words multiplied for the purpose, that white is black, and black is white, according as they are paid" (p. 231). This fairly describes Plato's view of the sophist, and he complained that while they were skilled at multiplying words to win an argument, they were also paid for their services. And because money was on the line, truth became less important than victory.

It may seem a bit strange, but this is where Heraclitus and Parmenides come back into the picture. While Athenian philosophers debated the merits of the respective positions advanced by these two Presocratics, the sophists-who were, after all, philosopherswere also interested in the question of whether the nature of reality is a state of permanence or a state of change. However, the sophists responded to the conflict between Heraclitus and Parmenides by rejecting the need to make a choice at all. The sophists regarded the debate as indicative of a problem at the heart of the philosophy of knowledge itself: the problem of ultimate undecidability. The sophists refused to pick one side or the other, and instead suggested that the debate between Heraclitus and Parmenides only proved that no one could ever know which side was right. Maybe the universe is changing; maybe the universe is always the same. Both men had good arguments supporting their respective positions. As it was impossible to determine who was right in this debate, the Presocratics said that it would be far wiser to doubt the power of reason to lead us to truth. For the sophists, the issue was not really whether the nature of reality was one of permanence or change; the issue was which position could be argued successfully on a particular occasion to win over an audience. Better to win by backing an incorrect theory than to lose by arguing for a correct one.

This may sound like a defeatist attitude. There is more to it than mere defeatism, however, for the sophists were part of the philosophical tradition of skepticism. Indeed, they are often described as radical exponents of skepticism, namely, the philosophic position of doubting the possibility of any true knowledge. For instance, Protagoras, the best known of the sophists, made the skeptical argument that since there is no way that anyone can know for certain the truth of reality, reality can only be described as possessing the qualities that some individual chooses to claim for it-an argument that would appear to result in the position that anything is true so long as someone believes it is true. This argument terminates in the maxim that truth is relative to the speaker.

Skepticism is certainly an interesting philosophy, but I am not going to pursue that subject further here. The point I want to emphasize is that the sophists approached the debate between Heraclitus and Parmenides by regarding one side as being as good as 
the other, a relativistic approach to the problem with significant consequences. After all, if absolute truth is unknowable, as the sophists reasoned, then searching for the supreme truth of anything is a fool's game. Therefore, the sophists felt justified in teaching people how to speak persuasively for the purpose of winning their argument or court proceeding. Getting to the truth of the matter was not important; what was important, was being victorious. Thus, although Heraclitus and Parmenides represent the opposing sides of a metaphysical question concerning the nature of reality, the sophists drew a quite non-metaphysical conclusion from that debate and made it central to their practical ambitions: win the argument at all costs because no one can know the absolute truth of the matter anyway.

Plato was concerned that teaching people how to argue effectively without regard for the truth was simply wrong and stood in stark contrast to his own philosophical interests. Plato disliked the sophists' acceptance of skepticism, for he contended that the search for truth is the goal of all philosophical inquiry, not something that can be pushed to the side as irrelevant or unimportant. His philosophical ambition was a lifelong quest to discover the truth, so it is unsurprising that he would be unsympathetic to anyone who denied that truth was even discoverable. Time and again in the dialogues, Plato shows Socrates explaining the value of dialectic as the search for the truth. But the sophists were plainly uninterested in getting to the truth in the way that Plato favoured, and by dispensing with the dialectical method in favour of speech-making, they further earned his disapproval. ${ }^{12}$

Plato also believed that there are ethical standards to which everyone should be obedient. Some things, he averred, are just wrong. The sophists, in line with their epistemological relativism, were also moral relativists. This is the argument adopted by the Milesian Presocratics, you will recall, but there is a slight difference here. Unlike the Milesians, who stayed in their city state and had strangers from across Asia minor come to them, the sophists travelled a great deal to earn a living by teaching the art of public speaking. Hence, the sophists had considerable knowledge of the customs and practices of other cultures, making them disinclined to believe that any one society could legitimately claim that its moral code was the pinnacle of ethical practice. Of course, this is precisely what Plato did claim, and he found it disconcerting to hear someone say that what is morally right is whatever your culture happens to believe is morally right. Moral correctness, the sophists maintained, is contextual, and completely dependent on the socio-historical circumstances of the people in question. Moral truths were not rooted in some grand, cosmological law consonant with the universe. They were instead the products of men and women here on earth trying to figure out the best way to organize their social lives.

The sophists were indebted to no particular moral or political tradition; their primary ambition was to make money by teaching their students the necessary techniques for effective persuasion; and they were epistemological and moral relativists. Just like modern-day marketers, the cynic might observe, the sophists were not deeply concerned with the truth of what was said because they were convinced that no single truth even existed. Furthermore, because their students generally came from members of the upper classes who had the financial resources to employ a rhetoric tutor, the sophists had a class bias, and thus they were often regarded warily by the lower classes.
VOLUME 12 / ISSUE 1 / 2021 


\section{Scholarly and Research}

\section{Communication}

VOLUME 12 / ISSUE 1 / 2021
Moreover, because they were paid for their instruction, Plato (and later Aristotle) saw them as undermining the true ends of philosophical inquiry that both Plato and Aristotle said was the honest search for the truth.

These are the main points concerning Plato's relationship with the sophists I want to highlight, yet there is one further point I would be remiss not to mention. Most historians today argue that it is doubtful that the sophists are fairly portrayed in Plato's works, and many of the things I have just said about them were probably exaggerated so that Plato could make his own position nobler. His disdain for their procedures and beliefs greatly coloured what he wrote, and while he certainly got the general details correct, it is likely that the sophists were somewhat less despicable than they are portrayed in the dialogues. Their moral relativism was so hateful to Plato that historians generally concur that their doctrines and even their practices are probably misrepresented to some degree in the dialogues. What is clear, however, is that no misrepresentation of Plato's disapproval for their teachings appears in his works.

\section{Plato reconciles Heraclitus and Parmenides}

We have arrived at the point where we have two influences on Plato to consider: the debate between Heraclitus and Parmenides, and the role of the sophists in Athenian society. Both issues come together to form a foundation for the way that Plato came to understand the nature of rhetoric. Let me explain how he did this.

First, Plato's response to the debate between Heraclitus and Parmenides was to take a page out of the sophists' handbook by refusing to endorse one side or the other. But rather than slide into relativism in the manner of the sophists-a sin Plato would never have committed-he went in the opposite direction. In fact, Plato turned the argument inside out, and said it was not that neither Heraclitus nor Parmenides could be proven correct, as the sophists claimed, but that both Heraclitus and Parmenides were correct. In short, Plato claimed that things are always changing, even as he claimed that things are never changing. How did he maintain such an obviously contradictory view? Moreover, how did his claim that Heraclitus and Parmenides were both correct address his opposition to the sophists teaching the art of persuasion? The explanation reveals the ingenuity and intellectual elegance that characterizes much of Plato's philosophizing.

Plato said that the metaphysical problem of permanence versus change only appears irresolvable, and if placed in an appropriate context the answer is obvious. Heraclitus was correct, Plato argued, in saying that all nature was in flux because Heraclitus was looking at a specific part of the world, but not all of it. And Parmenides was also right, Plato maintained, because he was also looking at only a portion of the cosmos, and not all of it. Therefore, some things are permanent and some things are changing. It is as simple as that.

Naturally, Plato needed to explain how the cosmos could be divided up this way. The part of the world to which Heraclitus referred when he said that everything is in a state of constant change, therefore, is the world we see all around us, the visible world of plants, animals, humans, and so on. Heraclitus' philosophy applies only to the visible realm of the world, where we clearly see change happening all the time. On the other hand, the part of the cosmos Parmenides attended to is the invisible world, a realm that 
we know to exist but cannot see. Hence, the reason the debate existed at all was because no one before Plato had noticed that two different levels of reality were being discussed, and until we sort out the true nature of these two dimensions of the cosmos-the visible and the invisible-we will always appear to face a conundrum. Thus, Plato devised a way to resolve this problem by introducing what we call metaphysical dualism. This simply means that Plato divided reality into two domains, the visible and the invisible (or the visible and the intelligible), and then argued that these two realms can only be bridged by reason. And reason, as he conceptualized it, was the dialectical approach found in the dialogues, for it was this approach that did away with rhetorical language and focused exclusively on the truth of things. To connect the everyday world of tangible objects to the realm of ideas, then, it was necessary to make the ascent by using dialectical thought. We do not dispense with Heraclitus or Parmenides, then, but understand their ideas by situating them in their appropriate contexts.

This might sound like a promising solution, but it is probably still unclear what Plato was getting at. Why does he emphasize reason in saying that Heraclitus and Parmenides are both right? Before we consider the role of reason in Plato's metaphysics, we need to look at the two dimensions of reality that he identified in slightly more detail. Talking about the visible realm and the invisible or intelligible realm can certainly be confusing, so what exactly are these two realms? If there is a part of the cosmos that is invisible, how can we even discuss it? Let us start with what we cannot see, the invisible realm of metaphysical dualism.

You may be sufficiently familiar with Plato to know that the invisible aspect of realitythe world of permanence-is the realm of Ideal Forms. And if you know about this aspect of Platonic philosophy, you probably also know that the domain of Ideal Forms describes ideal, or perfect, conceptions of all the things and ideas that make up the universe. This aspect of reality stands outside of space and time. In the realm of the Ideal Forms, all things are universally true, unchanging, and immutable. This is the realm described by Parmenides, that aspect of reality where the eternal truths are to be found. What sorts of truth are unchanging and universal? Plato loved geometry, so consider the idea of a triangle, a three-sided figure of 180 degrees. The ideal of triangularity exists eternally and unchanging in the realm of the Ideal Forms; triangularity, then, is true whether a triangle is ever actually drawn in the visible realm. Indeed, the procedure of drawing a triangle is incidental to the theory of triangularity, for you can apprehend the principles of geometrical triangularity entirely in your mind. The concepts underlying triangles persist whether anyone picks up a pencil and draws one or not. The idea of the triangle is independent of any form of visible representation. You can know the truth of triangularity - the principle on which the ideal of the triangle is founded-without ever seeing or drawing one. The facts that the three sides of a triangle add up to 180 degrees or that the square of the hypotenuse of a right triangle is equal to the sum of the squares of the other two sides are true eternally. Moreover, these facts were true before humans were around to figure out the principles of geometry and they will be true when the last person has ceased thinking. It is not our thinking about triangularity that makes it true. The principles of triangularity are true even as they are independent of human thought. ${ }^{13}$ Triangularity is an ideal form that exists in the eternal and unchanging realm of invisible intelligibility.
VOLUME 12 / ISSUE 1 / 2021 


\section{Scholarly and Research}

\section{Communication}

VOLUME 12 / ISSUE 1 / 2021
The idea of love, in its perfect eternal nature, also exists in the realm of Ideal Forms, even if that ideal is never realized in any actual love relationship here on earth. And on we could go. Plato claimed that anything you can imagine, including beauty, friendship, and justice, have an ideal form in the eternal realm, and that what you and I encounter here on earth are merely imperfect copies of that ideal form. Why imperfect? They are imperfect because they exist in the visible realm and, therefore, are subject to the possibility of change. Further, access to the ideal realm is possible only through reason, which Plato narrowly associates with his method of inquiry known as the dialectic. The realm of Ideal Forms, then, is independent of us, for this is the domain of things that transcend all things human. Even if the earth ceased to exist and all people were to disappear, two plus two would still equal four eternally, unchanged, and for all time. In fact, the word truth hardly applies in the realm of Ideal Forms because being and truth are really one and the same. Or, as it might be said, being and truth are indissociable in the realm of invisible forms. In technical parlance, epistemology is ontology in paradise.

If the idea of a realm of Ideal Forms seems odd, you might think about it this way. In many religions, especially various Christian denominations, believers subscribe to the idea that heaven is a place where everything is perfect. And because heaven is a state of perfection, nothing can ever change. Why? Because perfection admits of no gradations, no degrees, and no stages. For an object to be perfectly beautiful, for example, is to be as beautiful as that object can possibly be. It is illogical, therefore, to say of the perfectly beautiful thing that it could be more beautiful because that would be admitting that the object was not perfectly beautiful to begin with. Nothing can be better in any way than a perfect thing.

Because nothing can be better once it has achieved perfection, things in heaven cannot improve. Therefore, if things in heaven were to change, the only direction they could change would be toward being less perfect, because the concept of better than perfect is contradictory. But if something in heaven did change, and it could only change by becoming less than perfect, then it would not be in heaven, where everything is perfect. So, we might think of Plato's realm of Ideal Forms as analogous to Christian notions of paradise-a common tactic for many Medieval theologians. It is only in such an abstract realm - only in a Christian heaven or Platonic dimension - that the notion of an ideal form can even make sense, although there are substantial reasons to question whether Plato's ideal realm itself even makes sense. Indeed, there are plenty of things to criticize regarding this theory, but that is not the point here. Despite the potential strangeness of his argument, Plato locates Parmenidean permanence in the domain of the intelligible - the eternal and unchanging realm of Ideal Forms.

It is not surprising, then, that Plato believed the domain of Heraclitean flux (the world of constant change) was found in the everyday reality of human existence, the world in which we find ourselves, the world of space and time. Thus, according to Plato, Heraclitus was correct to say that everything is in flux so long as we recognize that this is only true in the part of reality we know as the immediate world in which we live. In this part of reality, we find physical objects that are subject to change. Here on earth, in other words, things (including living bodies) grow, decay, and sometimes disappear. The world around is indeed a unity of oppositions in which change is abundantly obvious: water freezes and then melts; water boils and then condenses back into water. The world 
of physical objects is, therefore, that part of reality that corresponds to Heraclitus' metaphysics. In the material world it is true that Heraclitus cannot step into the same river twice, for in the material world change is the fundamental principle of all things.

The real question, then, is how we are to understand the relationship between the sphere of Ideal Forms and the world of everyday life. Plato's answer was to claim that physical objects are mere imitations of those objects whose essence is discovered in the realm of Ideal Forms. Let me give you one of his famous examples to clarify. According to Plato, there is a perfect form of justice that exists in its eternal and unchanging form in the domain of the Ideal Forms. Here on earth, however, we can only ever achieve a pale imitation of justice, for human justice is always flawed because it is always changing. So, justice as we apply it in our daily lives is a mere copy of the perfect form of justice. Another well-known Platonic example is the geometrical figure. You can probably accept that there is an idea of perfect circularity-not a particular circle that is perfect, of course, for that would be impossible for us to draw, but the idea of circularity as perfectly realized. Every circle you draw will at best be a poor imitation of the perfect circularity that is its guiding form. Indeed, we need these unattainable, perfect forms to provide us with an idea of what we should be striving for despite knowing that we can never really achieve the perfection of things as they exist in the domain of the Ideal Forms-at least, not here, in the realm of imperfect copies. In everything we do, everything we create, and every idea we posit, we are basing our actions on a belief in the perfect ideal version, but we are only ever able to achieve imperfect and changeable imitations here on earth.

You may find this notion absurd, but Plato took it seriously-or so he appears to, despite raising some interesting objections of his own. Still, he seems to have been generally disposed to the truth of his metaphysical dualism and used the argument to present some interesting cultural and political propositions. For instance, Plato (1997d) writes in Book X of The Republic that God creates only perfect things and ideas and, because he is divine, has no interest in making imperfect things. Thus, Plato suggests, that whereas God creates the perfect idea of a bed, carpenters can only imitate that form when they manufacture a bed. Not only that but artists who paint images of beds make even more imperfect copies (copies that are even less perfect), since a painting of a bed is a third-order copy of the perfect ideal bed. What is important in this example, as Plato said, is that "imitation is far removed from the truth, for it touches only a small part of each thing and a part that is itself only an image" (p. 1202). So, we live in a world filled with imitations, copies, and reflections of the real, ideal forms. This means that truth exists only in the realm of Ideal Forms, and that imitation, as he claims, "is far removed from the truth." To content ourselves with what we can know about the world and its copies is, therefore, to content ourselves with knowledge that will never rise to the true knowledge of the actual reality of things. Plato decides that a perfect society, a society that he tries to realize in his text The Republic, will have no artists since they produce mere copies that some people might mistakenly regard as the truth. All imitation in Plato's world is politically suspect.

\section{Plato's divided line}

You likely have recognized that Plato is preparing a place for the sophists in the change- 
Scholarly and Research Communication

VOLUME 12 / ISSUE 1 / 2021 able world of Heraclitus and reserving a place for the unchanging truth in the eternal realm of the Ideal Forms, the world of Parmenides. In fact, this would suggest that rhetoric, which, after all, deals with change insofar as we seek to change people's minds by persuading them, is set apart, or "far removed" from the domain of truth. Plato resolves the conflict between Heraclitus and Parmenides by giving each of them a separate part of reality to occupy in his metaphysical dualism; and he deals with the problem of rhetoric by separating it off from truth and locating it in the shadowy world of Heraclitean flux. A diagram would be helpful to explain these ideas, and fortunately Plato suggests just such a guide.

Near the end of Book VI in The Republic (Plato, 1997d), Socrates explain to Glaucon ${ }^{14}$ most of the things I have just described, but he does so by making some further distinctions that show the direct nature of the relationship between his theory of knowledge and his view of rhetoric, alongside his attitudes toward the sophists. Socrates tells Glaucon that we can divide the world into things that are visible and things that are intelligible. Glaucon readily agrees with the logic of this division. Socrates then suggests that one way to understand the difference between the visible and intelligible is to imagine "a line divided into two unequal sections" (509d) with the world of the visible and the domain of the intelligible ordered along this divided line. The essential division that Socrates describes-and that represents Plato's theory of knowledge-allows us to distinguish between the material and the ideal, the intelligible and the visible, and knowledge and opinion. See Figure 1 for a reconstructed diagram with elaborations that are not in the description in The Republic.

Figure 1: Plato's divided line of knowledge

KNOWLEDGE
INTELLIGIBLE
ORDER

OPINION

VISIBLE

ORDER

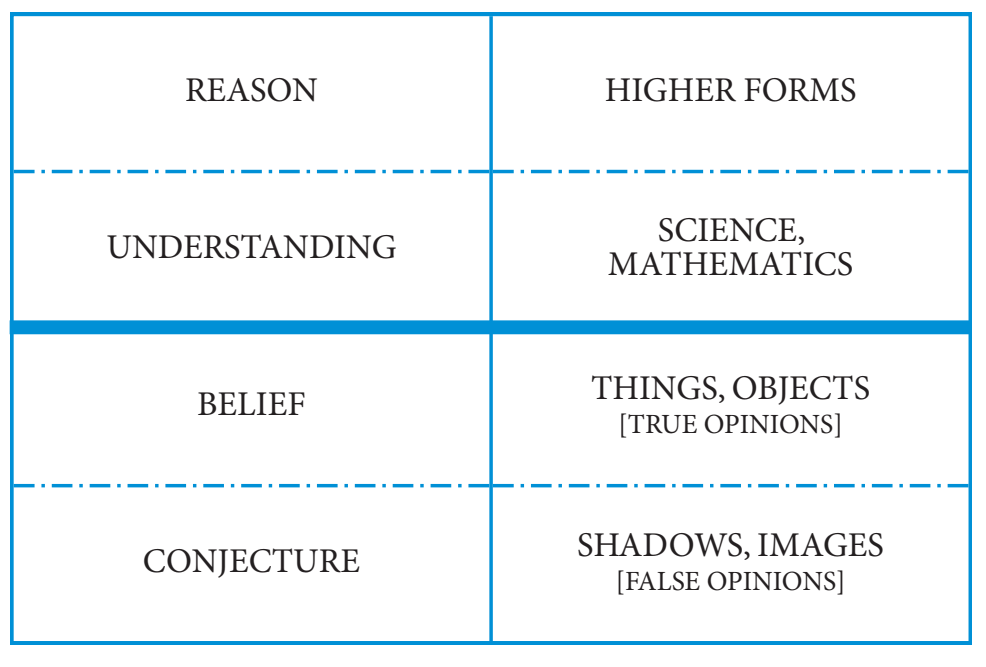

Parmenidean Permanence

Heraclitean Flux

In the lower section, the domain of visible objects, we find those forms of knowledge dependent on our senses. And the lowest of these forms of knowledge are the shadows and images we see in reflections in mirrors, in ponds, or as shadows on a wall. Placing these things at the furthest distance from truth makes sense insofar as we are probably less certain when we see a reflection of something than we are when we see the object directly. ${ }^{15}$ Indeed, you will note that in the domain of the visible order are modes of

McCarron, Gary. (2021). The McCarron Lectures. Lecture 3: Plato and Persuasion. Scholarly and Research Communication, 12(1). doi:10.22230/src.2021v12n1a367 
apprehension (ways of knowing) that are essentially uncertain. Shadows are less certain than the objects that throw shadows; conjectures are informed guesses rather than guaranteed knowledge; and beliefs, though sometimes strongly maintained, are not established truths. Hence, these ways of approaching the world exist in the visible realm, and, more significantly, each of them is characterized by the possibility of change. Conjectures may change as we come to see things more clearly, or beliefs may change as we accumulate more data about the phenomenon in question. Opinions may change as we hear further information. The fact that change dominates in the lower regions, of course, is partly a result of the fact of uncertainty, for opinions are liable to change just as conjectures may be modified when we learn we are making incorrect assumptions. This is the world of Heraclitean flux, or change.

As we ascend the scale and cross the divided line, you will note that we move toward increasingly abstract concepts thatvin Plato's argument-are universal. As we move toward these higher forms of knowledge, we leave behind opinion and approach the certainty of truth. Whereas the objects of perception (the visible realm) are concrete, the objects of intelligibility are abstract; whereas the objects of perception are individual things, the objects of intelligibility are general or universal concepts; and whereas the objects of perception are changeable, dynamically active, and in Heraclitean flux, the objects of intelligibility are unchanging, immutable, and in Parmenidean permanence.

Now you can see how the various threads of our discussion come together. Plato believed that persuasion is located below the divided line, in the realm of belief and conjecture, and that rhetoric - the practice of seeking to change people's minds-can only be effective in that part of the world where change is possible. Above the divided line are the absolute truths of mathematics and the principles of logic, a domain where change is impossible, for the things we find in the intelligible order are eternally true. Thus, rhetorical practices can never rise above the divided line; they cannot enter the realm of Ideal Forms because those forms are eternal, immutable, and eternally true. Rhetoric can only ever be effective in swaying people in respect of their opinions, their beliefs, and their conjectures. No matter how skilled the rhetor, she cannot persuade you that when you subtract three from ten you get eight, for this is simply untrue. But she may be able to persuade you to vote for a particular political candidate, to accept that a specific activity is immoral, or to agree that Toronto is better than Vancouver. Rhetoric can only be practiced in the world of conjectures and uncertainty; thus, instructing someone in the art of rhetoric is to teach them to live forever in the land of opinions. It is to deny them the skills needed to transcend this mundane world and seek the true meaning of life in the realm of the Ideal Forms. Heraclitus' philosophy of change was applicable in rhetoric, but Parmenides' thesis of permanence applied in the domain of logic and truth.

For Plato, then, truth is impervious to the eloquence of seduction-indeed, it makes no sense at all to say that I will try to persuade you of an analytic truth. ${ }^{16}$ What I can try to do, though, is persuade you that your opinion about something is wrong and that you should change your mind. This is certainly an important matter, for we often do things based entirely on opinion and belief, and it might be helpful to have someone offering guidance as to what to believe or how to behave. But Plato was an uncompromising

McCarron, Gary. (2021). The McCarron Lectures. Lecture 3: Plato and Persuasion. Scholarly and Research Communication, 12(1). doi:10.22230/src.2021v12n1a367 


\section{Scholarly and Research}

\section{Communication}

VOLUME 12 / ISSUE 1 / 2021 philosopher, for he believed that the search for the truth was an imperative that no man or woman should avoid. Persuasion, he tells us in the dialogue Gorgias (Plato, 1997a), is similar to choosing pastry over nutrition. It may give us immediate pleasure, but it does harm in the long run.

To say, then, that the sophists, whose ambitions were to change people's minds, were restricted in their practice to dealing with the lower forms of knowledge, is perhaps to say rather little in the contemporary context, for we are accustomed to people seeking to persuade us to change our opinions: to buy brand A rather than brand $\mathrm{B}$, or to agree that Guardians of the Galaxy (Gunn, 2014) is a better film than The Searchers (Ford, 1956). ${ }^{17}$ In Plato's terms, however, the assertion that the sophists could never rise to the condition of producing true knowledge was vitally important, and it led him to condemn all forms of sophistry and rhetoric as dangerous distractions from the truth. According to Plato, truth could only be discovered through reason and the dialectic; opinions, by contrast, were produced out of flattery and trickery. Hence Plato's disregard for the sophists was motivated in part by his belief that they were thwarting the search for knowledge at its highest level.

\section{Final thoughts on the dialectic}

I want to end this lecture with a few comments about the method of Plato's dialectic as he described it. There are many secondary accounts of what Plato meant by the dialectic, and how it can best be applied in contemporary philosophy and communication theory, but I want to present here only what Plato allows Socrates to say rather than encourage a debate regarding the "real" meaning of dialectic as it should be conceived by modern readers. If we stick to Socrates' words, it isn't terribly difficult. ${ }^{18}$

In fact, I have already given the main features in saying that Socrates spoke with people about important questions concerning politics, justice, and morality (among other things) and then asked them what they thought. Once they answered him, he often responded with a follow-up question that indicated how the original answer they gave might need revising. He would continue with a comment or question showing how that second response might also need rethinking. And in this way-via a question-andanswer format-Socrates could show that our understanding of things is often much weaker than we are aware.

For instance, in one dialogue Socrates asks, "What is justice?" only to be told that it involves giving back to others as they give to us. He initially appears to accept this answer, but then he asks whether we should return a weapon to a deranged and dangerous person. When his audience says, no, that would be wrong, Socrates then suggests that perhaps justice does not involve always and only returning in kind what was given to us, that justice, in other words, is not entirely explained by the principle of reciprocity. With that reformulation, his listeners are then forced to consider whether justice can be one thing in one case and another thing in a different case. In other words, Socrates shows through his subtle questioning that things are not always exactly as they seem, and that precision can be difficult to achieve. In working our way through the subject according to a dialectical model, Socrates avows, we draw ever closer to the ultimate truth we are seeking.

McCarron, Gary. (2021). The McCarron Lectures. Lecture 3: Plato and Persuasion. Scholarly and Research Communication, 12(1). doi:10.22230/src.2021v12n1a367 
Let me give an example of this dialectical process from the dialogue Gorgias (Plato, 1997a). Gorgias, who hailed from Leontini in Sicily, was a famed rhetorician, and the dialogue that bears his name nicely illustrates what I have said here regarding Plato's opposition to the teaching of persuasive speaking. Focus on a few lines beginning from 449d. At this point in the dialogue, Socrates has convinced Gorgias to answer Socrates' questions after Gorgias' young friend Polus has tried to answer on Gorgias' behalf, much to Socrates' disappointment. Now that he has Gorgias in his sights, Socrates asks him the question that has been on his mind since first he heard that Gorgias was in Athens and staying at the home of Callicles. That question, of course, is "What is rhetoric?"

Socrates: Come then. You claim to be knowledgeable in the craft of oratory [i.e., rhetoric] and to be able to make someone else an orator, too. With which of the things there are is oratory concerned? Weaving, for example, is concerned with the production of clothes, isn't it?

Gorgias: Yes.

Socrates: And so, too, music is concerned with the composition of tunes?

Gorgias: Yes.

Socrates: By Hera, Gorgias, I do like your answers. They couldn’t be shorter!

Gorgias: Yes, Socrates, I daresay I'm doing it quite nicely.

Socrates: And so you are. Come and answer me then that way about oratory, too. About which, of the things there are, is it knowledge?

Gorgias: About speeches.

Socrates: What sort of speeches, Gorgias? Those that explain how sick people should be treated to get well?

Gorgias: No.

Socrates: So oratory isn't concerned with all speeches.

Gorgias: Oh, no.

Socrates: But it does make people capable of speaking.

Gorgias: Yes.

Socrates: And also to be wise in what they're speaking about.

Gorgias: Of course.

Socrates: Now does the medical craft, the one we were talking about just now, make people able both to have wisdom about and to speak about the sick?

Gorgias: Necessarily.

Socrates: This craft, then, is evidently concerned with speeches too.

Gorgias: Yes.

Socrates: Speeches about diseases, that is? 


\section{Scholarly and Research}

\section{Communication}

VOLUME 12 / ISSUE 1 / 2021
Gorgias: Exactly.

Socrates: Isn't physical training also concerned with speeches, speeches about good and bad physical condition?

Gorgias: Yes, it is.

Socrates: In fact, Gorgias, the same is true of the other crafts, too. Each of them is concerned with those speeches that are about the object of the particular craft.

Gorgias: Apparently.

Socrates: Then why don't you call the other crafts oratory, since you call any craft whatever that's concerned with speeches oratory? They're concerned with speeches, too! (Plato, 1997a, pp. 795-796)

Socrates uses Gorgias' responses as a way of moving toward his goal. To say that he does not impose anything of his own on the conversation is disingenuous, of course, but for the most part, Socrates tries to act like a mirror and avoid directing Gorgias one way or the other. Nonetheless, he succeeds in showing to everyone in attendance that perhaps Gorgias himself, a highly trained and influential teacher of rhetoric, does not know the subject matter of his own discipline. It is also noteworthy that near the end of this section, Gorgias abandons his usual confidence in responding "Yes" to each question and observation and says, somewhat reluctantly, "Apparently." He has been forced to agree with Socrates not on account of Socrates' having bullied or coerced him to a conclusion he would rather not draw, but because the logic of the dialogue is irrefutable. Later in the dialogue, Gorgias explains exactly what sorts of speeches rhetoric is concerned with, and this enables Socrates to advance his criticism of rhetorical practices generally

So, the dialectical method as practiced here by Socrates is a simple question-andanswer format, where the interlocutor and the respondent co-construct a deeper and better understanding of the topic at hand. In the end, it is not surprising that neither Plato, Gorgias, Polus, Callicles, or any of the others in attendance at the meeting recorded in the Gorgias (Plato, 1997a) ultimately arrives at a perfect understanding of rhetoric. After all, in the visible realm of conjectures and opinions, absolute truth can hardly be expected. But the effort to clarify their respective understandings, and the attempt to build from a shaky foundation to a firmer conception of the matter at hand, is a crucial characteristic of what Plato is trying to accomplish in his dialogues.

In the end, of course, rhetoric comes off rather poorly in the Gorgias (Plato, 1997a) because Socrates insists on finding a definition that, frankly, may not exist, for perfect definitions for anything are certainly hard to come by. But his central point concerning the way that persuasion can only ever be used to advance and defend our beliefs, conjectures, and opinions is very important. This observation leads into a fuller understanding of what is known as the conviction/persuasion duality, the idea that the ideal forms require conviction and the imperfect copies here on earth are subject only to persuasive discourse. This is probably jumping ahead a bit too much, though. For now, let us be satisfied in noting that Plato is one of the first thinkers to present the art of persuasion in such a way as to show that it can sometimes be morally suspect. And his 
essential point that rhetoric can sometimes be a distraction from the truth remains an important argument to this day.

\section{Notes}

1. Socrates freely acknowledged that he was something of a pest and that his habit of questioning people annoyed many of his fellow citizens. In fact, in his defence before the Athenian court, as recorded by Plato (1997b) in the dialogue known as The Apology, Socrates refers to himself as a gadfly, meaning someone who interferes with the affairs of society by proposing novel and sometimes upsetting opinions, someone who is committed, in other words, to asking questions about the established customs and beliefs held in common by the members of a society. And because many people do not like to have their settled ways of life unsettled, Socrates was not always the most popular person to run across.

2. Plato is also regarded as the first person to use the word rhetoric (see Kennedy, 1999).

3. English translations of the dialogues vary in the way some terms and ideas are rendered. For instance, the word rhetoric is often translated as oratory. This word is related to exhortation, which refers to the procedure of encouraging, urging, or persuading.

4. A wonderful, if somewhat peculiar, recounting of this war is available online. Produced as a television docudrama, the film tells the story of the Peloponnesian War and features appearances by actors playing Socrates; Thucydides, a famous Greek historian; and, of course, Pericles (played by Ben Kingsley) (YouTube, 2010). It scores 8.6 on the Internet Movie Database. A tremendously detailed account of the war from the historian and classical scholar Jennifer T. Roberts (2017) shows how the struggle for the control of Greece continued long after Athens surrendered.

5. The story is related in the Socratic dialogue The Apology, 32c-d (Plato, 1997b). Leon is also mentioned in Xenophon's (1966) Hellenica (A History of My Times), but no mention of Socrates is made here. Given that the incident was important in turning Socrates against the Thirty, Xenophon's omission of that detail is curious.

6. Socrates did not apologize for his actions in the everyday sense of showing regret. The title Apology refers instead to apologia, which means "an explanation."

7. Dominic Pettman (2016) says that were we to update Heraclitus, we would say that "you never step in the same live stream twice" (p. xiii).

8. There are practical issues at stake here, too. Consider the person who apologizes by telling you that she is not the same person she was when she committed the offense; or think about the prisoner who petitions for release based on the claim to have reformed (i.e., changed). I believe that as a general rule it is reasonable to acknowledge that people change, though I am equally aware that some people claim to have reformed only to deceive us later. People can be self-serving, but people can also genuinely turn over a new leaf and change in quite remarkable ways. And yet, the changed person must be the initial person for their claims to have changed or reformed to make any difference to us. It can be very confusing.

9. Cratylus' claim, preposterous though it sounds, is reported in Aristotle's (1999) Metaphysics. 


\section{Scholarly and Research}

\section{Communication}

VOLUME 12 / ISSUE 1 / 2021
10. As with many Presocratic writings, we have fragments of this poem only. However, it is useful to realize that the use of verse was rather common in ancient Athens, even in works of a scientific character.

11. Since I have touched on etymology already, I should add that the word sophist originally had no negative or positive connotations at all and corresponded roughly to today's word for professor.

12. In the Gorgias (Plato, 1997a), Socrates compliments Gorgias for avoiding speeches in favour of simple yes or no answers to the questions Socrates asks. This is not just an illustration of Socrates wanting to control the dialogue but also exemplifies his notion of how the dialectical method should work. Because speeches can contain similes, metaphors, flowery language, and figures of speech, Socrates preferred the short yes-or-no style of interrogation that made so-called fancy speech difficult.

13. I will add without detailed explanation that some philosophers would dispute this claim, but it was true for Plato and it is his philosophy I am elaborating.

14. Glaucon, who was the older brother of Socrates, appears as a frequent conversant with Socrates in The Republic (Plato, 1997d), and is mentioned in several dialogues, as well.

15. Plato means more than just actual reflections, though, for he is also speaking of artists who manufacture imitations and copies. Recall that Plato was suspicious of all forms of communication that use images, such as painting, poetry, sculpture, drama, and religious rituals, because these art forms use images to provide fantasy rather than truth. Plato especially feared that the passions of the public are easily stimulated, influenced, and controlled by such persuasive imagery, hence his view that that the lowest kind of knowledge was rooted in images and conjecture.

16. An analytic truth just means a statement that is true on its face. "All bachelors are unmarried men," is analytically true because it is true by virtue of its meaning, not by virtue of how it relates to the world. Analytic truth differs from so-called synthetic truth. "All red roses are red" is analytically true. "All roses in my garden are red" is synthetically true, since you would need to examine the world (my garden, in this case) to determine whether it is true. An analytic truth never requires that you confirm its truth by appealing to the world of actual things, whereas a synthetic truth naturally requires that you look to the evidence to see whether or not it is true.

17. As if.

18. See Burke (1969).

\section{References}

Aristotle. (1999). Metaphysics (H. Lawson-Tancred, Trans). Harmondsworth, UK: Penguin Books.

Burke, Kenneth. (1969). A grammar of motives. Berkeley, CA \& Los Angeles, CA: University of California Press.

Burke, Kenneth. (1984). Permanence and change: An anatomy of purpose (3d ed.). Berkeley, CA, \& Los Angeles, CA: University of California Press.

Clark, Michael. (2002). Paradoxes from A to Z. London, UK, \& New York, NY: Routledge Books. Ford, John (Director). The searchers [Film]. Hollywood, CA: Warner Brothers.

Gunn, James (Director). (2014). Guardians of the galaxy [Film]. Burbank, CA: Marvel Studios. Kennedy, George. (1999). Classical rhetoric and its Christian and secular tradition from ancient to modern times (2nd ed.). Chapel Hill, NC, \& London, UK: The University of North Carolina Press.

McCarron, Gary. (2021). The McCarron Lectures. Lecture 3: Plato and Persuasion. Scholarly and Research Communication, 12(1). doi:10.22230/src.2021v12n1a367 
Pettman, Dominic. (2016). Infinite distraction: Paying attention to social media. Cambridge, UK: Polity Press.

Plato. (1997a). Gorgias (D.J. Zeyl, Trans.). In J.M. Cooper (Ed.), Plato: Complete works (pp. 791-869). Indianapolis, IN, \& Cambridge, UK: Hackett Publishing Company.

Plato. (1997b). The apology (G.M.A. Grube, Trans.). In J.M. Cooper (Ed.), Plato: Complete works (pp. 17-36). Indianapolis, IN, \& Cambridge, UK: Hackett Publishing Company.

Plato. (1997c). The laws (T.J. Saunders, Trans.). In J.M. Cooper (Ed.), Plato: Complete works (pp. 13181616). Indianapolis and Cambridge: Hackett Publishing Company, 1997, pp. 1318-1616. Indianapolis, IN, \& Cambridge, UK: Hackett Publishing Company.

Plato. (1997d). The republic (G.M.A. Grube, Trans.) (revised by C.D.C. Reeve.). In J.M. Cooper (Ed.), Plato: Complete works (pp. 917-1223). Indianapolis, IN, \& Cambridge, UK: Hackett Publishing Company.

Plato. (1997e). The symposium (A. Nehamas \& P. Woodruff, Trans.). In J.M. Cooper (Ed.), Plato: Complete works (pp. 457-505). Indianapolis, IN, \& Cambridge, UK: Hackett Publishing Company.

Roberts, Jennifer T. (2017). The plague of war: Athens, Sparta, and the struggle for ancient Greece. Oxford, UK, \& New York, NY: Oxford University Press.

Swift, Jonathan. (2005). Gulliver's travels. Oxford, UK: Oxford University Press. (Originally published in 1726)

Xenophon. (1966). Hellenica: A history of my times (B. Warner, Trans.). Harmondsworth, UK: Penguin Books. YouTube. (2010, December 30). The war that never ends [Video]. YouTube. URL: https://www.youtube.com/watch?v=SNcJ79qPIg8 [July 1, 2020].

\section{Scholarly and Research}

\section{Communication}

VOLUME 12 / ISSUE 1 / 2021

McCarron, Gary. (2021). The McCarron Lectures. Lecture 3: Plato and Persuasion. Scholarly and 